\title{
Struktur Komunitas Mollusca Bentik Berbasis Kekeruhan Di Perairan Pelabuhan Tanjung Emas Semarang
}

\author{
Jafron Wasiq Hidayat, Karyadi Baskoro, Rini Sopiany \\ Lab. Ekologi dan Biosistematik Jurusan Biologi FMIPA UNDIP
}

\begin{abstract}
The breakwater of Tanjung Emas Seaport is designed to absorb seawave as well as increase ships stability. Such water stability will trigger the light and small particles to deposite onto the bottom of the water body, eventhough these are easily re-suspended and initiate to create turbidity. Turbididty is one factor affecting Mollusc community. In facing the global climate changes, there will be a seriuos problem triggering the turbidity of the seawater and so do the organims. Researh were aimed to study the benthic Mollusc community in different turbidity levels. Justified ramdom sampling was applied in 14 stations. Community structure of the molluscs were analized discriptively as well as through Shannon-Wiener (H') and evenness (e) indeces.

Result showed that turbidity in PTES varies between 06,750 - 45,250 NTU. Such qualities were relatively high range and can be tolerated by several given species, mainly Gafrarium tumidum, Nuculana acuta and Pyrene sp. These three above species could live within such high turbidity levels, since some of material are part of their diets without disturbing their respiration fuction. The highest diversity index $H^{\prime}$ was 1,68 and found in Station 5, which is in accordance with its highest turbididyt level 45,250 NTU. The smalest turbidity level occured in Station 8 and it was related to smaller diversity index $(0,24)$. There was a tendency, the smaller the turbidity levels the smaller the diversity indices. Such relatonship was consistence to the other three stations, namely 9,10 and 11. Exception was found in Station 1, where different dominant species occured and diversity index was relatively high. It is believed these are related to the presence of warm outlet of Indonesia Power sewage reaching 32,5 centdegree.
\end{abstract}

Key words: Tanjung Emas Seaport, Mollusca, Turbidity

\section{PENDAHULUAN}

Pelabuhan Tanjung Emas Semarang (PTES) merupakan salah satu infrastruktur wilayah Jawa Tengah yang berskala internasional. Fasilitas pelabuhan dilengkapi dengan 'breakwater' sebagai sarana untuk mengurangi hempasan ombak dan memperbesar stabilitas kapal. Redaman ombak akan memicu terjadinya sedimentasi, khususnya material yang berukuran kecil semisal lumpur dan liat (Middleton, 1993; Nybakken, 1992). Terlebih lagi pada perairan tersebut dekat dengan muara sungai Kali Semarang yang sangat tinggi kontribusinya dalam hal meterial terlarut. Sifat meterial kecil dan ringan, sangat mudah ter-resuspensi oleh pergerakan air dan kapal. Hal ini menjadikan perairan menjadi mudah keruh dan sangat mempengaruhi kehidupan dari tingkat dasar yaitu plankton, hingga ikan dan Mollusca benthik .

Memasuki era pemanasan global, maka akan terjadi kenaikan suhu muka laut yang berdampak terjadinya intensitas hujan yang lebih besar, kenaikan paras muka laut, banjir di daerah rendah, perubahan bentang garis pantai dan perubahan hidro-oceanografis lainnya (Beatley et, al, 2002; Dahuri, 2002). Terjadinya banjir dan kenaikan paras muka laut secara langsung akan menggeser garis pantai melebihi ketinggian normal sehingga melewati pertahanan alami terakhir, yaitu hutan dan komunitas mangrove. Hempasan ombak yang akan terjadi cenderung menghantam daratan yang tidak terlindungi, sehingga akresi akan luas terjadi. Akresi akan mengurai tanah/ daratan menghasilkan material lepas, baik berupa partikel kasar maupun halus. Material tersebut akan mengikuti arus air, menjadi penyebab kekeruhan dan/ atau mengendap pada kondisi perairan yang tenang (Middleton, 1993). Kondisi yang akan terjadi di atas, identik dengan kondisi yang saat ini berlangsung di perairan PTES; dimana lalulintas dan kondisi hidrografi mendukung terjadinya kekeruhan tinggi.

Kehidupan Mollusca bentik secara umum dipengaruhi oleh kualitas perairannya, antara lain jenis substrat tempat hidup, kekeruhan, $\mathrm{pH}$, suhu, salinitas, kandungan oksigen terlarut dan polutan 
(Norse \& Crowder 2005; Nybakken, 1992). Material penyebab kekeruhan sendiri antara lain berupa partikel tanah liat, lumpur, bahan organik terurai, plankton, bakteri air dan organisme mikroskopis lainnya (EPA, 1999). Mollusca, disamping kelompok cacing, merupakan kelompok yang banyak hidup di perairan bersubstrat lumpur yang mengandung bahan organik tinggi, baik terlarut maupun terendapkan. Substrat lumpur merupakan akumulasi partikel ringan dan kecil yang semula merupakan komponen kekeruhan (Middleton, 1993). Bahan-bahan tersebut merupakan pakan yang potensial bagi Mollusca benthik, khususnya filter feeder dan deposit feeder. Menurut EPA (1999), kekeruhan secara umum mengganggu biota dikarenakan akan menghalangi masuknya sinar matahari bagi kebutuhan fotosistesis fitoplankton, menurunkan kesediaan oksgen terlarut, memicu sedimentasi penyebab pendangkalan, mengganggu pandangan visual hewan, mempengaruhi perilaku dan sistem makan (termasuk interaksi biota) dan pernafasan hewan. Disamping itu juga menyebabkan merebaknya patogen dan predator. Pada kondisi kekeruhan yang tinggi, maka pengaruh di atas akan semakin nyata yaitu menimbulkan gangguan-gangguan; antara lain penurunan kualitas air, penyumbatan insang, penimbunan telur dan larva, dan kematian karena sebab primer ataupun sekunder (EPA, 1999; Hargreaves, 1999)

Penelitian bertujuan untuk mengetahui keanekaragaman dan kelimpahan Mollusca bentik pada berbagai tingkat kekeruhan di perairan PTES serta mengetahui hubungan antara populasi Mollusca dominan dengan kekeruhan. Hasil dari penelitian ini diharapakan dapat memberikan gambaran potensi gangguan kekeruhan terhadap kehidupan Mollusca bentik dan/ atau aspek budidayanya saat pemanasan global makin nyata berlangsung.

\section{BAHAN DAN METODE}

\section{Metode Sampling}

Penelitian dilakukan di dalam area 'breakwater' Pelabuhan Tanjung Emas Semarang. Sampling dilakukan pada musim kemarau, antara bulan Agustus - Oktober 2006. Sampel biota diambil secara judgement random sampling, menggunakan Eckman dradger ukuran $0,025 \mathrm{~m}^{2}$. Sejumlah 14 station dipilih secara berpendar dengan GPS (seperti tertera pada Gambar 01) dengan 3 kali ulangan dan diakumulasikan menjadi satu. Sejumlah parameter fisiko-kimia, yaitu kekeruhan, $\mathrm{pH}$, suhu, salinitas, konduktifitas dan DO diukur dengan menggunakan 'water checker' Hariba U-10 pada setiap station. Sampel lumpur yang diperoleh selanjutnya disortir dengan ayakan ukuran mesh (size) $0,5 \mathrm{~mm}$. Spesimen yang didapat dimasukkan ke dalam kantong plastik dengan diberi larutan pengawet alkohol 70\% dan formalin $4 \%$. Sampel siap diidentifikasi di laboratorium.

\section{Analisis Laboratorium}

Sampel yang diperoleh diidentifikasi hingga tingkat jenis atau paling tidak tingkat Familia di Laboratorium Ekologi \& Biosistematik, FMIPA UNDIP. Disamping itu juga dilakukan penghitungan jumlah jenis dan individu secara menyeluruh. Identifikasi mengacu pada sejumlah referensi antara lain Dharma (1998), Jutting (1993), Robert (1982), Sabelli (1980).

\section{Analisis Data}

Data identifikasi jenis dan jumlah individu masing masing jenis dianalisis struktur komunitasnya dengan melihat kemelimpahan dan keanekaragaman jenis. Data jenis yang memiliki dominasi dan kemelimpahan tinggi atau jenis spesifik akan dianalisis secara diskriptif terkait dengan data fisik kimia yang ada. Nilai Kelimpahan relatif $(\mathrm{Kr})$ digunakan untuk menggambarkan parameter dominansi spesies. Formula dari analisis tersebut adalah sebagai berikut :

$$
\begin{aligned}
& \mathrm{Kr}={ }^{\mathrm{ni}} /_{\mathrm{N}} \mathrm{x} 100 \% \text {, dimana } \\
& \mathrm{Kr}: \text { Kelimpahan relatif } \\
& \mathrm{ni}: \text { Jumlah individu jenis ke-i } \\
& \mathrm{N}: \text { Jumlah individu total semua jenis }
\end{aligned}
$$

Jorgensen (1974) mengkategorisasikan nilai Kerapatan relatif ke dalam tiga kreteria berikut

- $\mathrm{Kr}>5 \%$ merupakan jenis dominan

- $2 \%<\mathrm{Kr}<5 \%$ merupakan jenis sub-dominan

- $\mathrm{Kr}<2 \%$ merupakan jenis tidak dominan. 
Analisis struktur komunitas menggunakan indeks Shannon-Wiener $\left(\mathrm{H}^{\prime}\right)$ dan indek perataan jenis (e), dilakukan untuk mengetahui kestabilan masing-masing station terkait dengan faktor kekeruhan. Formula Indeks keanekaragaman Shannon-Wiener (H') adalah sebagai berikut,

$$
\mathrm{H}^{\prime}=-\sum_{i=1}^{s} \mathrm{~N} \ln \mathrm{x} \frac{\mathrm{m}}{\mathrm{N}}, \text { dimana }
$$

$\mathrm{H}^{\prime} \quad=$ Indeks keanekargaman jenis

$\mathrm{ni}=$ Jumlah individu jenis ke-i

$\mathrm{N}=$ Jumlah total individu

Ln = logaritme bilangan dasar

Menurut Lee et al (1978), kondisi kestabilan suatu kemunitas dibedakan menjadi 3 kreteri berdasarkan indeks H' tersebut, masing-masing :
- Jika $\mathrm{H}^{\prime}<1$, berarti komunitas dalam keadaan tidak stabil

- Jika $1<\mathrm{H}^{\prime}<3$, berarti komunitas dalam keadaan sedang kestabilannya

- Jika H'>3, berarti komunitas dalam keadaan stabil

Untuk memastikan akurasi nilai indeks H' maka seringkali didukung indeks Perataan Jenis (e). Nilai indeks e berkisar antara $0-1$ mengindikasikan adanya faktor dominansi jenis satu terhadap yang lain. Indeks e diformulasikan dengan rumus berikut :

$$
\mathrm{e}=\frac{\mathrm{H}^{\prime}}{\ln \mathrm{S}} \text {,dimana }
$$

$\mathrm{e}=$ indeks perataan jenis.

$\mathrm{H}^{\prime}=$ Indeks keanekaragaman jenis ShannonWiener.

$\mathrm{S}=$ jumlah species.

Gambar 01. Peta lokasi sampling di dalam area 'breakwater' Pelabuhan Tanjung Emas Semarang

\section{HASIL DAN PEMBAHASAN}

Secara umum species yang di dapatkan di perairan PTES sejumlah 36 jenis Mollusca. Jenis yang paling banyak dan ditemukan di semua station adalah Gafrarium tumidum diikuti Nuculana acuta dan Pyrene sp. Jenis G. tumidum memiliki kelimpahan antara 10 sampai 1703 individu per $\mathrm{m}^{2}$. Kepadatan tertinggi dijumpai 
pada Station 7, sedangkan yang terendah di Station 1. Jenis Nuculana acuta memiliki kepadatan tertinggi sebesar 47 individu per $\mathrm{m}^{2}$ dan ditemukan luas diarea kajian, kecuali Station 7. Adapun jenis Pyrene sp dengan kepadatan 24 individu per $\mathrm{m}^{2}$, keberadaannya luas kecuali Station 1 dan 9. Hasil analisis selengkapnya tertera pada Tabel 01 . Jenis G. tumidum memiliki kesesuaian tempat yang paling baik, mengingat jenis tersebut kelimpahannya paling besar. Keberadaan substrat berlumpur hasil akumulasi meterial kekeruhan merupakan media hidup yang paling cocok bagi kehidupan jenis tersebut. Hal ini seperti yang dikemukakan oleh Roberts dkk (1982) yang menyatakan bahwa habitat tempat hidup $G$. tumidum berada di substrat berlumpur. Lumpur tersebut bermula dari material tersuspensi (merupakan komponen kekeruhan) yang mengendap karena kondisi hidrografi (Middleton, 1993).

Jenis Nuculana acuta dan Pyrene sp, nampaknya tidak setangguh $G$. tumidum dalam menghadapi faktor kekeruhan. Kelimpahannya relatif kecil bahkan pada beberapa station jenisjenis tersebut menghilang. Meskipun demikian ketiga jenis tersebut secara parsial merupakan jenis dominan (indek $\mathrm{Kr}>5 \%$ ), yang mempengaruhi langsung ataupun tidak bagi kehidupan jenis lainnya. Jenis Anadara granosa, Phapia undulata, Truncatella sp juga dijumpai secara luas, kecuali pada Station 1. Jenis-jenis tersebut berdasarkan nilai kelimpahan relatifnya termasuk jenis sub-dominan $(2 \%<\mathrm{Kr}<5 \%)$ yang kurang / tidak mengganggu kehidupan jenis lain. Kebanyakan jenis-jenis di atas habitatnya di substrat berlumpur dan berlumpur pasiran yang banyak mengandung komponen organik (de Bruyne, 2003; Roberts dkk, 1982). Keberadaan dan kelimpahannya menandakan bahwa pengadukan (yang membentuk kekeruhan) dan/ atau penimbunan lumpur yang disebabkan aktifitas kapal maupun arus tidak/ sedikit mengganggu secara fungsi terhadap kehidupan jenis-jenis tersebut. Bahan-bahan tersebut pada kondisi tertentu dapat dimanfaatkan sebagai makanan, khususnya yang berstatus deposit dan filter feeder. Namun demikian, akumulasi lumpur yang besar dapat menyebabkan kematian, terutama diindikasikan dari banyaknya cangkang kecil yang mati pada sampel substrat/ lumpur. Bagi jenisjenis komersial, seperti kerang darah (Anadara granosa) dan kerang hijau (Mytilus edulis) tekanan populasi lebih dikarenakan adanya penangkapan oleh nelayan.

Station 1 merupakan pengecualian, dimana hampir semua jenis-jenis dominan di atas menjadi menurun kepadatannya dan dominasinya digantikan oleh jenis lain. Jenis pengganti dominasi tersebut a.1 Terebralia pollustris, Serpulorbis sp dan Mytilus viridis. Pengecualian di atas disebabkan adanya polutan yang berupa limbah air panas sisa pendingin instalasi PLTU yang menyebabkan air menjadi lebih panas mencapai $32,5^{\circ} \mathrm{C}$. Pada station ini jenis Terebralia pollustris jumlahnya justru terbanyak yaitu 122 individu per $\mathrm{m}^{2}$ dan semakin menjauh ke laut jumlahnya semakin kecil. Jenis $T$. pollustris mempunyai ketahanan yang besar terhadap kegaraman yang rendah bahkan dapat dijumpai pada tambak payau. Jenis tersebut pada umumnya sangat tahan perairan yang tercemar, khususnya bahan organik. Jenis ini juga tahan terhadap panas disebabkan tempat hidupnya umumnya di daerah yang masih terkena pasang surut dan daerah mangrove ( Dharma, 1998; Roberts dkk, 1982) dan sering terdedah udara terbuka yang panas saat surut. Adapun keberadaan Mytilus edulis yang melimpah di Station 1 dan tidak dijumpai / sedikit di area lain disebabkan adanya substrat bebatuan di sekitar garis pantai yang merupakan kebutuhan utama bagi penempelan tubuhnya (Nybakken, 1992).

Dalam hal kajian komunitas melalui analisis nilai indeks $\mathrm{H}^{\prime}$, didapatkan hasil nilai indeks keanekaragaman perairan PTES bervariasi antara 0,24 hingga 1,68. Berdasarkan kriteria Lee et al (1978), nilai tersebut termasuk perairan yang kurang stabil hingga sedang. Gangguan kestabilan tersebut dapat berupa adanya polutan, penangkapan, kondisi hidrografi, interaksi biologis, dll. Penangkapan ikan secara nyata akan mengurangi kelimpahan ikan dan dengan demikian potensi predasi oleh ikan dan nekton lain. 
Tabel 01. Kelimpahan dan keanekaragaman jenis Mollusca bentik di perairan Pelabuhan Tanjung Emas Semarang

\begin{tabular}{|c|c|c|c|c|c|c|c|c|c|c|c|c|c|c|c|}
\hline \multirow[t]{2}{*}{ No } & \multirow{2}{*}{$\begin{array}{c}\text { Nama } \\
\text { Species }\end{array}$} & \multicolumn{14}{|c|}{ Jumlah individu per $\mathrm{m}^{2}$ pada station } \\
\hline & & 1 & 2 & 3 & 4 & 5 & 6 & 7 & 8 & 9 & $\mathbf{1 0}$ & 11 & 12 & 13 & 14 \\
\hline $\mathbf{A}$ & BIVALVIA & & & & & & & & & & & & & & \\
\hline 1 & Anadara granosa & 0 & 9 & 10 & 2 & 4 & 2 & 13 & 6 & 5 & 5 & 5 & 9 & 10 & 10 \\
\hline 2 & Anomia simplex & 0 & 0 & 0 & 0 & 0 & 0 & 0 & 0 & 0 & 1 & 0 & 0 & 0 & 2 \\
\hline 3 & Artica $s p$ & 0 & 0 & 0 & 0 & 0 & 0 & 2 & 0 & 0 & 0 & 0 & 0 & 6 & 0 \\
\hline 4 & Atactodea striata & 0 & 3 & 0 & 0 & 0 & 0 & 0 & 0 & 2 & 0 & 0 & 0 & 0 & 0 \\
\hline 5 & Barbatia $s p$ & 0 & 0 & 0 & 0 & 0 & 0 & 0 & 0 & 0 & 2 & 0 & 0 & 0 & 0 \\
\hline 6 & Camptopallium $s p$ & 0 & 0 & 0 & 0 & 0 & 0 & 0 & 0 & 0 & 1 & 0 & 0 & 0 & 0 \\
\hline 7 & Davila plana & 0 & 7 & 10 & 2 & 117 & 19 & 2 & 0 & 1 & 0 & 0 & 3 & 5 & 2 \\
\hline 8 & Dentalium $s p$ & 0 & 4 & 1 & 2 & 23 & 1 & 0 & 0 & 3 & 1 & 2 & 0 & 0 & 11 \\
\hline 9 & Gafrarium tumidum & 10 & 342 & 547 & 266 & 166 & 768 & 1703 & 1383 & 870 & 769 & 617 & 823 & 1541 & 1136 \\
\hline 10 & Isognomon perna & 0 & 0 & 0 & 0 & 0 & 0 & 0 & 0 & 0 & 5 & 0 & 0 & 0 & 0 \\
\hline 11 & Libitina rostrata & 0 & 0 & 3 & 1 & 0 & 1 & 1 & 1 & 0 & 0 & 0 & 1 & 1 & 0 \\
\hline 12 & Lithopaga gracilis & 0 & 3 & 0 & 10 & 6 & 2 & 0 & 5 & 1 & 6 & 0 & 0 & 1 & 0 \\
\hline 13 & Lutraria incurva & 4 & 0 & 0 & 0 & 0 & 0 & 0 & 0 & 0 & 0 & 0 & 0 & 0 & 0 \\
\hline 14 & Mytilus viridis & 10 & 0 & 0 & 0 & 0 & 0 & 0 & 0 & 0 & 5 & 0 & 0 & 3 & 0 \\
\hline 15 & Nuculana acuta & 7 & 15 & 22 & 47 & 10 & 1 & 0 & 6 & 5 & 43 & 7 & 8 & 7 & 14 \\
\hline 16 & Phapia undulata & 0 & 7 & 7 & 7 & 7 & 3 & 1 & 5 & 11 & 5 & 11 & 3 & 7 & 10 \\
\hline 17 & Pholas orientalis & 0 & 5 & 5 & 0 & 13 & 8 & 17 & 2 & 3 & 7 & 6 & 5 & 6 & 1 \\
\hline 18 & Pinna muricata & 0 & 1 & 0 & 0 & 0 & 0 & 0 & 0 & 0 & 0 & 0 & 0 & 0 & 0 \\
\hline 19 & Pitar manillae & 0 & 2 & 3 & 0 & 0 & 0 & 0 & 0 & 0 & 0 & 0 & 0 & 2 & 0 \\
\hline 20 & Placamen $s p$ & 0 & 0 & 0 & 0 & 0 & 0 & 1 & 0 & 0 & 0 & 0 & 0 & 0 & 0 \\
\hline 21 & Tellina verrucosa & 0 & 7 & 3 & 10 & 12 & 2 & 1 & 3 & 3 & 8 & 9 & 0 & 6 & 0 \\
\hline 22 & Vulsella $s p$ & 0 & 0 & 0 & 0 & 0 & 0 & 0 & 0 & 0 & 0 & 0 & 0 & 1 & 0 \\
\hline $\mathbf{B}$ & GASTROPODA & & & & & & & & & & & & & & \\
\hline 23 & Architectonica $s p$ & 0 & 1 & 0 & 0 & 0 & 0 & 0 & 0 & 0 & 7 & 1 & 0 & 1 & 1 \\
\hline 24 & Epitonium $s p$ & 0 & 0 & 0 & 0 & 1 & 0 & 0 & 0 & 0 & 0 & 0 & 0 & 0 & 0 \\
\hline 25 & Gemmula kieneri & 0 & 2 & 0 & 2 & 2 & 1 & 3 & 1 & 1 & 2 & 0 & 2 & 1 & 2 \\
\hline 26 & Murex tribulus & 0 & 0 & 0 & 0 & 0 & 0 & 0 & 0 & 0 & 1 & 0 & 0 & 0 & 0 \\
\hline 27 & Nassarius $s p$ & 2 & 3 & 1 & 2 & 3 & 0 & 2 & 1 & 0 & 2 & 4 & 0 & 1 & 0 \\
\hline 28 & Natica $s p$ & 0 & 0 & 0 & 0 & 0 & 0 & 0 & 0 & 0 & 4 & 0 & 0 & 1 & 1 \\
\hline 29 & Oliva oliva & 0 & 2 & 0 & 0 & 0 & 1 & 3 & 0 & 4 & 4 & 0 & 0 & 1 & 2 \\
\hline 30 & Peristernia sp & 0 & 1 & 0 & 0 & 0 & 1 & 1 & 1 & 0 & 1 & 0 & 0 & 0 & 0 \\
\hline 31 & Pyrene sp & 0 & 21 & 18 & 6 & 13 & 8 & 24 & 8 & 0 & 10 & 5 & 5 & 11 & 8 \\
\hline 32 & Serpulorbis $s p$ & 30 & 0 & 3 & 0 & 0 & 0 & 0 & 0 & 4 & 1 & 3 & 0 & 7 & 0 \\
\hline 33 & Terebralia pollustris & 122 & 5 & 1 & 0 & 2 & 0 & 1 & 0 & 0 & 0 & 0 & 0 & 0 & 0 \\
\hline 34 & Truncatella $s p$ & 0 & 1 & 16 & 8 & 5 & 5 & 15 & 12 & 3 & 6 & 5 & 12 & 8 & 7 \\
\hline 35 & Turbo broneus & 0 & 1 & 0 & 0 & 0 & 0 & 0 & 1 & 0 & 0 & 1 & 0 & 2 & 1 \\
\hline 36 & Turritella terebra & 0 & 0 & 0 & 0 & 0 & 0 & 0 & 1 & 49 & 7 & 1 & 0 & 1 & 3 \\
\hline
\end{tabular}

Tabel 02. Total jumlah individu, jumlah spesies, indeks H' dan indeks e komunitas plankton di Pelabuhan Tanjung Emas Semarang

\begin{tabular}{llllccccccccccc}
\hline Station & \multicolumn{1}{c}{$\mathbf{1}$} & $\mathbf{2}$ & $\mathbf{3}$ & $\mathbf{4}$ & \multicolumn{1}{c}{$\mathbf{5}$} & $\mathbf{6}$ & $\mathbf{7}$ & $\mathbf{8}$ & \multicolumn{1}{c}{$\mathbf{9}$} & $\mathbf{1 0}$ & $\mathbf{1 1}$ & $\mathbf{1 2}$ & $\mathbf{1 3}$ & \multicolumn{1}{c}{14} \\
\hline Juml Individu & $\mathbf{1 8 5}$ & $\mathbf{4 4 2}$ & $\mathbf{6 5 0}$ & $\mathbf{3 6 5}$ & $\mathbf{3 8 4}$ & $\mathbf{8 2 3}$ & $\mathbf{1 7 9 0}$ & $\mathbf{1 4 3 6}$ & $\mathbf{9 6 4}$ & $\mathbf{9 0 3}$ & $\mathbf{6 7 7}$ & $\mathbf{8 7 1}$ & $\mathbf{1 6 3 0}$ & $\mathbf{1 2 1 1}$ \\
Juml spesies & $\mathbf{7}$ & $\mathbf{2 1}$ & $\mathbf{1 5}$ & $\mathbf{1 3}$ & $\mathbf{1 5}$ & $\mathbf{1 5}$ & $\mathbf{1 6}$ & $\mathbf{1 5}$ & $\mathbf{1 5}$ & $\mathbf{2 4}$ & $\mathbf{1 4}$ & $\mathbf{1 0}$ & $\mathbf{2 3}$ & $\mathbf{1 6}$ \\
Indeks H & $\mathbf{1 , 1 4}$ & $\mathbf{1 , 1 2}$ & $\mathbf{0 , 7 9}$ & $\mathbf{1 , 0 6}$ & $\mathbf{1 , 6 8}$ & $\mathbf{0 , 3 2}$ & $\mathbf{0 , 2 9}$ & $\mathbf{0 , 2 4}$ & $\mathbf{0 , 4 9}$ & $\mathbf{0 , 8 0}$ & $\mathbf{0 , 5 1}$ & $\mathbf{0 , 3 2}$ & $\mathbf{0 . 3 6}$ & $\mathbf{0 , 3 8}$ \\
Indeks e & $\mathbf{0 , 2 9}$ & $\mathbf{0 , 2 4}$ & $\mathbf{0 , 1 6}$ & $\mathbf{0 , 4 1}$ & $\mathbf{0 , 3 7}$ & $\mathbf{0 , 0 6}$ & $\mathbf{0 , 0 5}$ & $\mathbf{0 , 0 4}$ & $\mathbf{0 , 1 8}$ & $\mathbf{0 , 1 5}$ & $\mathbf{0 , 1 9}$ & $\mathbf{0 , 0 6}$ & $\mathbf{0 , 0 6}$ & $\mathbf{0 , 0 7}$ \\
\hline
\end{tabular}


Dalam kaitanya dengan terjadinya polusi, besaran nilai kestabilan tersebut menandakan perairan tercemar berat hingga sedang (Lee at al, 1978). Komponen pencemar yang paling potensial berupa lumpur (faktor kekeruhan), suhu, minyak atau bahan kimia lain. Mollusca dikenal sebagai organisme bioakumulator yang dapat me-regulasi polutan minyak (Beiras \& His, 1995) dan logam berat (Nybakken, 1992). Dengan demikian, diyakini kedua jenis polutan tersebut tidak/ atau sedikit mengganggu kehidupan Mollusca.
Sementara polutan suhu (thermal), secara umum merubah komposisi jenis dominan, tetapi tidak mengganggu stabilitas ekosistem (indeks $\mathrm{H}^{\prime}$ ). Secara fisik-kimia, diantara parameter yang diukur (kecuali kekeruhan) tidak menunjukkan adanya kisaran yang kontras; baik DO, salinitas, suhu dan konduktivitas. Dengan demikian diyakini dalam hal ini, komponen pencemarnya yang menonjol adalah kekeruhan. Hasil pengukuran data fisik kimia selengkapnya seperti tertera pada Gambar 02 .

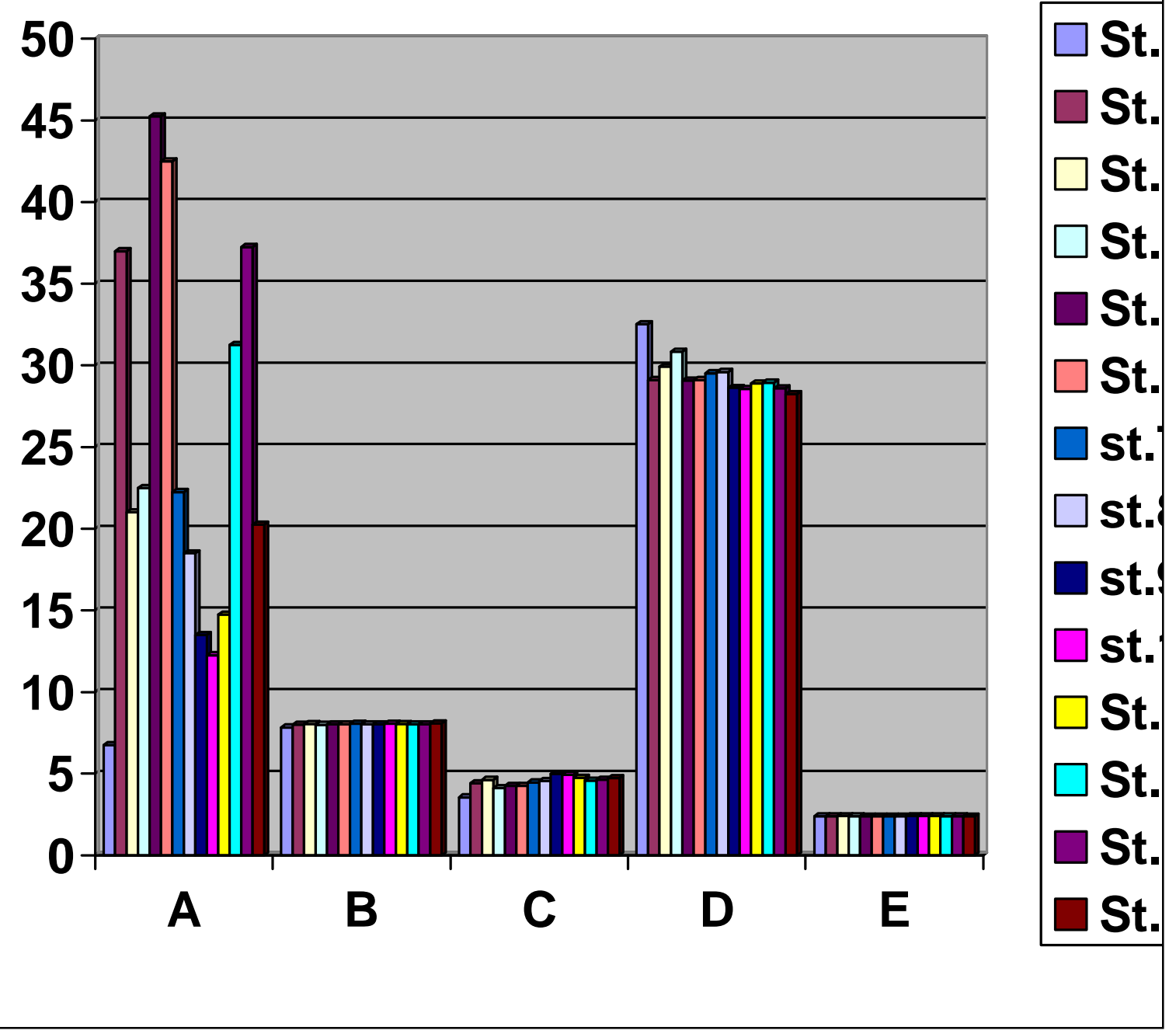

Gambar 02. Data pengukutan kekeruhan (A), pH (B), DO (C), suhu (D) dan salinitas (E) di PTES 
Nilai indeks H' tertinggi berada di Staton 5, dapat diartikan bahwa kondisi Station 5 merupakan daerah yang paling stabil, dimana interaksi biologis berjalan paling baik (Norse \& Crowder, 2005). Hal ini juga didukung besaran dari nilai e yang nilainya juga terbesar (meskipun hanya) yaitu 0,41. Nilai e tersebut mengindikasikan banyak sedikitnya jenis dominan (secara aktifitas) yang dapat mengganggu keberadaan jenis lainnya (Magguran, 1989). Nilai indeks e sebesar 0,41 cenderung memperlihatkan adanya dominasi spesies pada Station 5, paling tidak oleh $G$ tumidum. Kondisi kestabilan terbesar kedua adalah Station 1 dengan indeks H' sebesar 1,14 dan diikuti Station 2 dengan indeks $\mathrm{H}^{\prime}$ sebesar 1,12.

Pada ketiga station tersebut terlihat bahwa kekeruhan behubungan denga struktur komunitas. Sebagai bukti pembanding dapat dilihat Station 8 yang secara kekeruhan memiliki nilai yang rendah tetapi dengan kondisi fisik kimia lain yang relatif sama dengan ke tiga station tersebut, memperlihatkan nilai kestabilan indeks $\mathrm{H}^{\prime}$ yang rendah juga (H'sebesar 0,24). Station 9,10 dan 11 juga konsisten dengan hal tersebut. Pengecualian pada Station 1, dimana meskipun secara kekeruhan paling ringan, tetapi disana terdapat limbah suhu panas PLTU yang menyebabkan nilai indeks $\mathrm{H}^{\text {' }}$ tetap relatif tinggi $(1,14)$

Secara umum kekeruhan perairan di area kajian bervariasi antara 6,75 sampai 45,25 NTU. Kekeruhan tertinggi terdapat pada Station 5 diikuti kekeruhan pada Station 6 (nilai 42,50 NTU) serta Station 2 dan 13; sedang yang terkecil berada di Station 1 dekat muara outlet PLTU Tambak Lorok. Berdasarkan analisis program menggunakan (software) Golden Surfer 8,0; diperoleh tampilan seperti tertera Gambar 03. Pada gambar tersebut terlihat ada dua formasi kekeruhan air yaitu satu pool di Station 2 dan kedua di Station 4,5 dan 6. Formasi kedua memanjang mendekati pertengahan Station 12 \& 13. Sementara Station 8,9, 10 memiliki kualitas kekeruhan yang relatif rendah dan terpisah dari dua pool di atas. Perubahan arus dan arah angin (musim) tentunya akan mempengaruhi formasi tersebut.
Mengacu kualitas kekeruhan dan indeks H', maka hubungan keduanya dapat direpresentasikan oleh jenis dominan Gafrarium tumidum dan Nuculana acuta. Hasil analisis regresi polinomial memperlihatkan, kedua jenis tersebut berturut-turut memiliki hubungan dengan kekeruhan yang mengikuti fungsi $\mathbf{Y}=\mathbf{- 5 1 1 , 2 4 +}$ $118,879 X-2,20835 X^{2}$ dan $Y=8,72129+$ $0,80857 X-0,02015 X^{2}$. Dalam hal ini diartikan bahwa sampai batas tertentu, semakin besar kekeruhannya maka semakin besar keduanya. Hal ini suatu indikasi jenis-jenis tersebut cukup toleran terhadap kekeruhan. Berdasarkan persamaan tersebut, terlihat bahwa puncak respon kedua biota tersebut terhadap kekeruhan berada disekitar nilai turbiditas 20-25 NTU. Jenis-jenis tersebut tidak terganggu oleh material yang tercurah dari atas kolom air, sekaligus cocok dan dapat memanfaatkan material tersebut sebagai makanan dan tempat berlindung (de Bruyne, 2003; Dharma, 1998, Robert dkk, 1982). Keberadaan material terlarut yang tinggi menunjang terbentuknya deposit bahan organik melalui sedimentasi (Middleton, 1993). Namun demikian jika kekeruhan semakin besar (lebih dari 30 NTU), maka akan terjadi penurunan populasi.

Beberapa jenis tidak menyukai keberadaan material tersuspensi tersebut semisal, Pitar manillae, Pinna muricata,

Lutraria incurva, dll. Ketiadaan / keterbatasan hewan-hewan tersebut disebabkan material kekeruhan menyebabkan gangguan. Gangguan sesaat akan ditanggapi dengan menghindar, namun demikian apabila gangguan menjadi semakin kuat akan direspon dengan terjadinya kerusakan organ badan. Menurut Kotowski (2006), EPA (1999), Hargreaves ((1999); kekeruhan dapat menyebabkan terjadinya kerusakan insang akibat terjadinya penyumbatan struktur penyaringanya. Selanjutnya hewan akan berkurang aktivitasnya sehingga berpotensi mengalami kematian secara langsung ataupun sebab sekunder. Disamping itu, kekeruhan juga menyebabkan terhambatnya penyinaran matahari ke dalam kolom air yang dapat menurunkan produktivitas primer perairan. Penurunan tersebut secara bersama sama dengan peningkatan suhu menyebabkan penurunan 
kandungan oksigen. Boleh jadi oksigen di kolom air masih terpenuhi, namun demikian oksigen yang mudah diserap dapat terbatas jika terjadi kekekeruhan dan penyumbatan. Disamping itu kekeruhan juga memicu munculnya pathogen sekaligus menurunkan daya tahan biota yang dapat mempengaruhi vitalitas hewan terhadap tekanan mekanik, kimiawi maupun biologis.

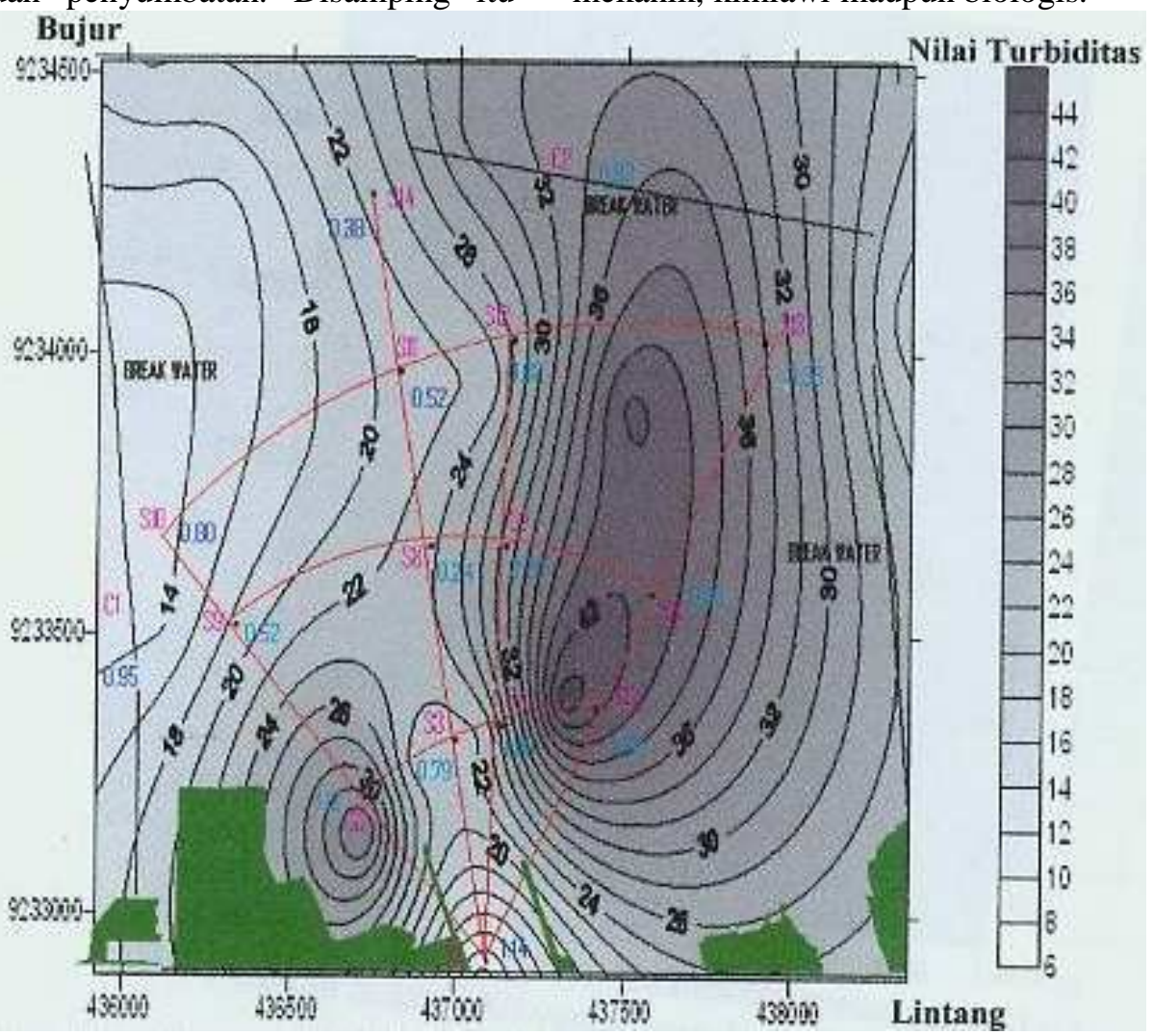

Gambar 03. Pola distribusi kekeruhan di perairan Pelabuhan Tanjung Emas Semarang

A. Grafarium tumidum (Y) vs turbididy $(\mathrm{X}) \quad$ B. Nuculalana acuta $(\mathrm{Y})$ vs turbidity $(\mathrm{X})$

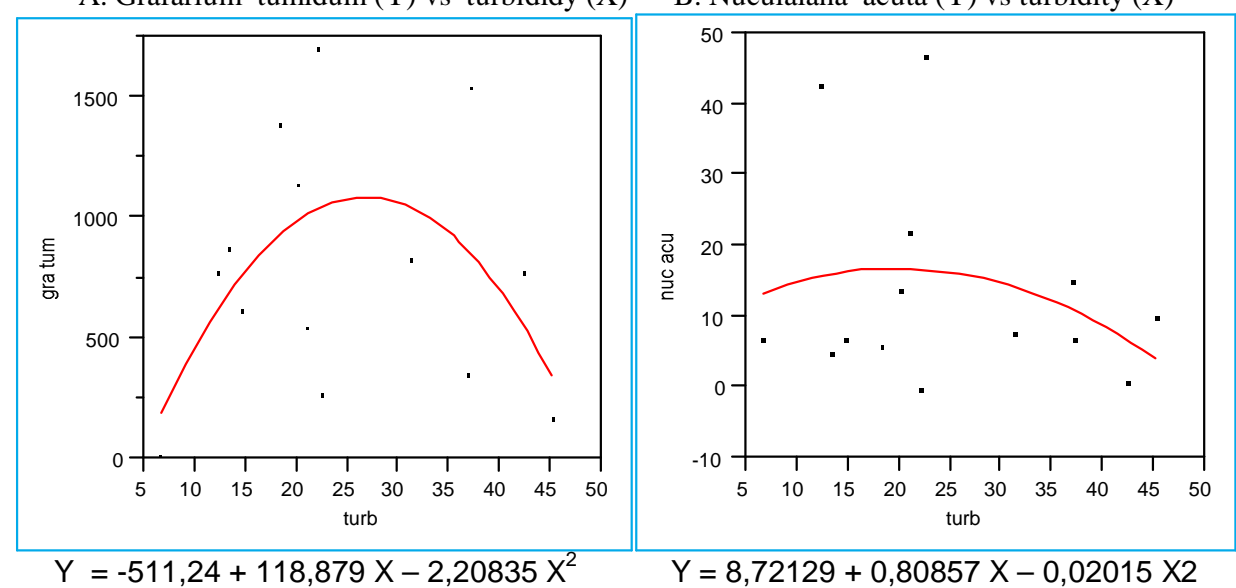

Gambar 04. Hubungan regresi polynomial antara G.tumidum dengan kekeruhan (A) dan Nuculana acuta dengan kekeruhan (B) 


\section{KESIMPULAN}

1. Pada perairan PTES minimal dijumpai 36 jenis Mollusca bentik, dimana dari sisi populasi jenis tertinggi kelimpahannya adalah Gafrarium tumidum, diikuti Nuculana acuta dan Pyrene sp.

2. Berdasarkan indeks keanekaragaman hayati $\left(\mathrm{H}^{\prime}\right)$ memperlihatkan perairan PTES memiliki kestabilan komunitas indeks $\mathrm{H}^{\prime}$ antara 0,24 sampai 1, 68 yaitu kestabilan rendah hingga sedang, dimana salah satunya disebabkan oleh gangguan faktor kekeruhan yang tinggi (bervariasi antara 6,75 sampai 45,25 NTU)

3. Komponen kekeruhan, setidaknya mempengaruhi kelimpahan $G$ tumidum dan Nuculana acuta dengan mengikuti bentuk hubungan $Y=-511,24+118,879 X-$ $2,20835 X^{2}$ dan $Y=8,72129+0,80857 X-$ $0,02015 X^{2}$., dimana pada kondisi yang rendah masih mendukung kehidupan, tetapi pada kondisi kekeruhan tinggi akan mengganggu.

\section{DAFTAR PUSTAKA}

Beatley, T., D.J. Brower, A.K. Schab, 2002, Coastal Zone Management, Island Press, Washington 329 pages.

Beiras, R and E. His, 1995, Toxicity of Fresh and Freeze-Dried Hydrocarbon PollutedSediment to Oyster Crassotrea gigas Embrio, Marine Pollution Bulletin, Vol .31 Ni.1 pp 47-49

Dahuri, R., 2002, Peran Iptek dalam Pembangunan Perikanan dan Kelautan secara Berkelanjutan, Seminar dan Lokakarya V MIPA Net, Universitas Negeri Jakarta, 2 Sep

de Bruyne, R.H., 2003, The Complete Encyclopedia of Shells. Rebo Publisher International, Lisse, 335 pages
Dharma, B., 1998, Siput dan Kerang Indonesia I (Indonesia Shell) PT Sarana Graha, Jakarta

EPA, 1999, EPA Guidance Manual. Importance Turbidity Provision, Google http : // www.epa.gov

Hargreaves, JA., 1999, Control of Cly Turbidity in Ponds, Google http : //www. aquanic.org

Jutting, BV, 1993, Syatematic Studies on the Non Marine Mollusca of the Indo-Australian Archipelago, Zoological Mosuem, London

Kotowski, J.E., 2006, Turbidity Minifact and Analysis, http ://www. interscience. wiley. com

Lee, C.D., S.B. Wang \& C.L. Kao, 1978, Benthic Macroinvertebrate and Fish as Biological Indicator of Water Quality with Reference to Community Diversity Index. In Quano E.A.R., Developing Countries, The Asian Intitute of Technology, London.

Magguran, AE., 1988, Ecological Diversity and Its Measurement, Chapman and Hall London

Middleton, G.V., 1993, Sedimen Deposit from Turbidity Current, http://www. annual review.org/ oranline

Norse, E.A. and L.B. Crowder, 2005, Marine Conservation Biology, Island Press Washington, 470 pages

Nybakken, J.W., 1992, Biologi Laut : Suatu Pendekatan Ekologis (alih bahasa : M.Eidmen, Koesbiono, D.G. Bengen, M. Hutomo \& S. Sukardjo) Cetakakn II PT Gramedia Jakarta

Roberts D, S.Soemodihardjo, W. Kastoro, 1982, Shallow Water Marine Molluscs of NorthWest Java, Lembaga oseanologi Nasional LIPI, Jakarta 